\section{Growth and Water Relations of Littleleaf Linden Trees Established in Irrigated Buffalograss and Kentucky Bluegrass}

\author{
J. Ryan Stewart, ${ }^{1}$ Roger Kjelgren, ${ }^{2}$ and Paul G. Johnson ${ }^{3}$ \\ Department of Plants, Soils, and Biometeorology, 4820 Old Main Hill, Utah State \\ University, Logan, UT 84322-4820
}

\author{
Michael R. Kuhns ${ }^{2}$ \\ Department of Forest, Range, and Wildlife Sciences, 5230 Old Main Hill, Utah \\ State University, Logan, UT 84322-5230
}

Additional index words. water stress, tree-turf competition, water relations, Tilia cordata, Poa
pratensis, Buchloë dactyloides, Bouteloua dactyloides, irrigation

\begin{abstract}
Although transplanted trees typically establish and grow without incident in frequently irrigated turfgrass, their performance in precisely irrigated turfgrass in an arid climate is not known. We investigated the effect of precision irrigation scheduling on growth and water relations of balled-and-burlapped littleleaf linden (Tilia cordata Mill. 'Greenspire') planted in buffalograss (Buchloë dactyloides [Nutt.] Engelm. 'Tatanka') and kentucky bluegrass (Poa pratensis $L_{\text {.). }}$. Over 2 years, trees in turfgrass were irrigated either by frequent replacement based on local reference evapotranspiration, or precision irrigated by estimating depletion of soil water to the point of incipient water stress for each turfgrass species. Predawn leaf water potential and stomatal conductance of trees were measured during first-year establishment, and predawn leaf water potential was measured during a mid-season water-deficit period during the second year. Trunk diameter growth and total tree leaf area were measured at the end of each year. Values of predawn leaf water potential and stomatal conductance of trees in precision-irrigated buffalograss were lower $\left(-0.65 \mathrm{MPa}, 25.3 \mathrm{mmol} \cdot \mathrm{m}^{-2} \cdot \mathrm{s}^{-1}\right)$ than those of trees in the other treatments near the end of the first growing season. The longer interval between precision irrigations resulted in mild water stress, but was not manifested in growth differences among trees across treatments during the first season. During the water-deficit period of the second year, there was no evidence of stress among the trees regardless of treatment. At the end of the second season, total leaf area of trees grown in precision-irrigated kentucky bluegrass $\left(1.10 \pm 0.34 \mathrm{~m}^{2}\right)$ was $46 \%$ of that of trees grown in buffalograss $\left(2.39 \pm 0.82 \mathrm{~m}^{2}\right)$ that were irrigated frequently. Trunk diameter growth of trees in frequently irrigated kentucky bluegrass $(1.91 \pm 2.65 \mathrm{~mm})$ was $29 \%$ of that of the trees grown in buffalograss $(6.68 \pm 1.68 \mathrm{~mm})$, regardless of irrigation treatment, suggesting a competition effect from kentucky bluegrass. We conclude that frequent irrigation of balled-and-burlapped trees in turfgrass, particularly buffalograss, is more conducive to tree health during establishment than is maximizing the interval between turfgrass irrigation. Regardless of irrigation schedule, kentucky bluegrass appears to impact tree growth severely during establishment in an arid climate.
\end{abstract}

Water conservation in irrigated urban landscapes across the United States is becoming increasingly important as human populations increase and drought strains existing water supplies (Kjelgren et al., 2000b). Turfgrass, particularly a cool-season species such as kentucky bluegrass, is a principal component of landscape irrigation and is a major focus of water conservation. Precise scheduling of irrigation is an important method for conserving landscape irrigation water. Another important conservation approach is to use lower-water-use plant material. In much of the western United States, buffalograss, a species native to the Great Plains of North America, is becoming more popular because of its low water

Received for publication 13 Aug. 2004. Accepted for publication 27 Dec. 2004. This research was supported by the Utah StateUniv.Agricultural ExperimentStation, Logan. Approved as journal paper no. 7601. Mention of trademark, proprietary product, or vendor does not constitute a guarantee or warranty of the product by Utah State Univ. and does not imply approval to the exclusion of other products. Paper submitted to fulfill partial requirement of a MS degree.
requirement(Klingenberg, 1992; Mintenkoetal., 2002). Grasses, however, are only one component of landscapes.

Trees are monetarily and aesthetically valuable parts of most landscapes, and many are planted into the turfgrass matrix that covers many ornamental landscapes. Trees planted in a densely vegetative ground cover are always in competition for water (Caldwell, 1987). The degree of competition is a function of the vegetation-free zone around the tree; the larger the zone, the less the competition. Kentucky bluegrass is particularly competitive for water due to high water uptake near the surface (Beard, 1973; Watson, 1988; Watson and Himelick, 1982), with roots concentrated in the upper $0.3 \mathrm{~m}$ of soil (Beard, 1973; Gist and Smith, 1948). Trees avoid competition with turfgrass by extending roots below those of the grass (Dawson et al., 2001; Hernández-Leos, 1998) to a depth of 1 to 2 m (Atkinson, 1980; Laiche et al., 1983), thereby accessing more water(Dawson, 1993). However, this adaptation may not be effective when trees are planted in buffalograss, which extends roots down to $0.9 \mathrm{~m}$ (Klingenberg, 1992; Weaver, 1958), and thus is more capable of depleting water in lower soil layers (Belsky, 1994).

The impact of turfgrass competition on trees is often masked in irrigated landscapes in which all vegetation typically receive sufficient water from over-watering with nonuniform irrigation systems (Kjelgren et al., 2000a). As irrigation systems are improved, however, to apply water more uniformly and precisely, turfgrass is often pushed to the threshold of water stress. Under these conditions, the competition for water between trees and turfgrass will increase. The magnitude of this impact is not fully understood, particularly for newly transplanted trees.

Newly transplanted trees are more susceptible to water stress than established trees (Kozlowski, 1975) because of their limited rootzones(Belsky, 1994). This is particularly true of balled-and-burlapped trees, where over $95 \%$ of the root system is lost during harvest (Watson and Himelick, 1982). Establishing balled-and-burlapped trees in soils covered with precision-irrigated kentucky bluegrass sod will likely increase competition for water in the upper soil layers. We hypothesize that transplanting a tree into a precision-irrigated stand of buffalograss increases water competition and stress because buffalograss has a potentially deeper root system that can compete with tree roots. This possibility has not yet been investigated, but should be considering the potential impact on growth and development of newly transplanted trees.

Our objective for this study was to compare the effect of precision-irrigation scheduling versus frequent-irrigation scheduling over 2 years on growth and water relations of balledand-burlapped littleleaf lindens planted in well-established buffalograss and kentucky bluegrass sod.

\section{Materials and Methods}

In April 1998, 20 plots, each $6 \times 6 \mathrm{~m}$, were laid out in a randomized complete block design with four replications at a research farm north of Logan, Utah, on a Millville silt loam (coarsesilty, carbonatic, mesic Typic Haploxerolls). Field capacity $(-0.03 \mathrm{MPa})$ and wilting point of the soil $(-1.5 \mathrm{MPa})$ were 0.25 and $0.10 \mathrm{~m}^{3} \cdot \mathrm{m}^{-3}$, respectively, for the particular soil type (Or, 1990). The level plots were divided by a $1-\mathrm{m}$ border to prevent sprinkler overlap into adjacent plots. Eight plots were seeded with buffalograss and another eight plots were seeded with an unknown genotype of kentucky bluegrass. Four additional plots were nonvegetated controls covered with coarse hardwood mulch $10 \mathrm{~cm}$ deep. Agear-drive sprinkler system (model 55059; Orbit Inc., Salt LakeCity, Utah) was installed in the 16 plots with one sprinkler head at each of the four corners. A distribution-uniformity test was conducted to determine the average application rate, and a correction factor was used to increase application rate to account for areas of uneven application (Stewart et al., 2004). The average application rate was $25 \mathrm{~mm} \cdot \mathrm{h}^{-1}$ and the average distribution uniformity was 0.72 . Adrip system with $11-\mathrm{L} \cdot \mathrm{h}^{-1}$ emitters was installed at the base of each tree in the four mulched plots. Turfgrass plots were allowed to establish during the growing season in 
1998. During the summer of 1999 the turfgrass was maintained under well-watered conditions except during a water-deficit treatment period in August when the point of incipient water stress and root depth were determined for both turfgrass species (Stewart et al., 2004). On 31 Mar. 2000, a field-grown, balled-and-burlapped 'Greenspire' littleleaf linden, averaging $30 \mathrm{~mm}$ in caliper 0.3 $\mathrm{m}$ above the tree base, was planted in the center of each plot.

During the 2000 and 2001 growing seasons, the plots were maintained under similar conditions for both turfgrass species. Plots were mowed once every $7 \mathrm{~d}$ to a height of $8 \mathrm{~cm}$ with a rotary mower; the clippings were collected and removed. The plots were broadcast-fertilized with $49 \mathrm{~kg} \cdot \mathrm{ha}^{-1}$ Milorganite $(6.8 \mathrm{~N}-2.3 \mathrm{P}-0 \mathrm{~K})$ and 49 $\mathrm{kg} \cdot \mathrm{ha}^{-1}$ ammonium sulfate $(21 \mathrm{~N}-0 \mathrm{P}-0 \mathrm{~K})$ in May 2000 and $98 \mathrm{~kg} \cdot \mathrm{ha}^{-1}$ ammonium sulfate in May 2001. The trees werealso fertilized at $250 \mathrm{~g} /$ tree by hand with Osmocote $(18 \mathrm{~N}-6 \mathrm{P}-12 \mathrm{~K})$ pellets at the base of each tree in May of both years. Broadleaf weeds were controlled in all turfgrass plots by spraying with a selective postemergentherbicide (Confront; Dow AgroSciences, Indianapolis, Ind.) at recommended rates. We controlled coolseason, weedy grasses in dormant buffalograss by spraying in early spring with a nonselective postemergentherbicide(Roundup; Monsanto, St. Louis, Mo.). A 1-m-diameter turfgrass-free area was maintained around the trunk of each tree by mulch and spot spraying with Roundup.

Two irrigation-scheduling treatments were applied in 2000 and 2001, both based on estimating turfgrass water loss as a function of local reference evapotranspiration (ET). A data logger (model CR10X; Campbell Scientific, Logan, Utah), located $0.3 \mathrm{~km}$ from the study area, estimated $\mathrm{ET}_{\mathrm{o}}$ on a hourly basis with an online algorithm based on the Penman-Monteith UNFAO-24 equation(Allen etal., 1989). To estimate ET, the data logger was equipped with a model CS500 probe (Campbell Scientific), a pyranometer(LI200SX; LI-COR, Lincoln, Nebr.), and an anemometer (model 034A-L; Met One, Grants Pass, Ore.) to measure relative humidity and air temperature; incoming shortwave radiation; and windspeed, respectively. Precipitation was also measured with a tipping bucket rain gauge (model TE525MM; Texas Electronics, Dallas, Texas); precipitation was subtracted from ET when calculating irrigation requirements. $\mathrm{ET}^{\circ}$ data was downloaded daily to calculate irrigation requirements. Turfgrass water loss was estimated from the product ofET and a fractional turfgrasswater-loss coefficient. The water-loss coefficients for buffalograss and kentucky bluegrass were 0.65 and 0.8, respectively (Ervin and Koski, 1998; Kneebone et al., 1992).

Soil moisture was monitored twice per week at $0.3-\mathrm{m}$ increments with a Hydroprobe neutron depth-moisture gauge (model 503 DR; Campbell Pacific Nuclear, Martinez, Calif.) in access tubes (0.04-m-diameter PVC pipe) located $1.5 \mathrm{~m}$ from the center of each plot and installed vertically to a depth of $2 \mathrm{~m}$. Since the Hydroprobe can not measure volumetric water content near the soil surface, a volumetric water-content sensor (HydroSense CS620; Campbell Scientific) was used to measure soil water content in the top $0.15 \mathrm{~m}$ of soil.
The first irrigation treatment was defined as frequent-replacement-irrigated; turfgrass was irrigated to replace estimated turfgrass water loss every 3 to $4 \mathrm{~d}$. The amount of water applied at each irrigation varied depending upon weather conditions affecting ET. Frequently irrigated plots of both turfgrass species were irrigated in 2000 on $12,15,18,21,24,27$, and 30 June; 3 , $6,10,13,17,20,24,27$, and $31 \mathrm{July}$; and 3, 7, $10,14,17,21$, and 24 Aug. In 2000, the estimated total amount of water applied per plot to frequent-replacement-irrigated buffalograss and kentucky bluegrass plots was 9018 and $11090 \mathrm{~L}$, respectively. In 2001, frequently irrigated plots of both turfgrass species were irrigated on 14, 19, 23, and 27 June; 2, 6, 9, 13, 16, 20, 24, and 28 July; and 1 Aug. The estimated total amount of water applied to the frequent-replacementirrigated buffalograss and kentucky bluegrass plots was $7144 \mathrm{~L}$ each.

The second irrigation treatment was defined as precision-irrigated. Depletion of soil water within the root zone of each species was tracked with neutron probe and Hydrosense measurements until the point of incipient water stress was reached (Stewart et. al., 2004). This value was previously determined for buffalograss and kentucky bluegrass (Stewart et al., 2004). At that point, the turfgrass was irrigated to apply the total amount of water estimated to have transpired since the previous irrigation based on the rooting depth of both species where the highest concentration of roots were distributed. The highestconcentration of roots of buffalograss and kentucky bluegrass were $60 \mathrm{~cm}$ and $30 \mathrm{~cm}$ from the surface, respectively (Stewart et al., 2004). Precision-irrigated plots of buffalograss were irrigated in 2000 on 24 June; 1, 11, and 21 July; and 8 Aug. Precision-irrigated plots of kentucky bluegrass were irrigated in 2000 on 16, 21, and 30 June; 6, 11, 21, and 28 July; and 8, 15, and 22 Aug. The estimated total amount of water applied perplot in 2000 to the precision-irrigated buffalograss and kentucky bluegrass plots was 8457 and 10721 L, respectively. In 2001, precision-irrigated plots of buffalograss were irrigated on 14, 19, 23 June; and 2 and 12 July. Precision-irrigated plots of kentucky bluegrass were irrigated in 2001 on $14,19,20,23$, and 27 June; and 2, 8, 12, and 21 July. In 2001, the estimated total amount of water applied per plot to the precision-irrigated buffalograss and kentucky bluegrass plots was 7870 and $6968 \mathrm{~L}$, respectively. The trees in the control plots were watered at least once a week for two hours. In 2000 and 2001, 261 and 191 L were applied per tree, respectively to the trees in the control plots.

Irrigation was withheld from all plots from 3 Aug. until 12 Sept. 2001 to determine if the turfgrass and irrigation treatments affected the susceptibility of trees to water stress. There was no precipitation during the period without irrigation.

The 30-year average daily maximum air temperatures for June, July, and August were 27, 31 , and $30^{\circ} \mathrm{C}$, respectively (http://www.wrcc.dri. edu/cgi-bin/cliMAIN.pl?utlogu). Daily maximum air temperatures in 2000 during June, July, and August were 33,38 , and $31^{\circ} \mathrm{C}$, respectively. Cumulative ET for June through August was 477 $\mathrm{mm}$ versus an average $555 \mathrm{~mm}$ (Ashcroft et al.,
1992). However, total precipitation for the same period was $52 \mathrm{~mm}$, while the 30-year average for this period was $84 \mathrm{~mm}$ (http://www.wrec.dri. edu/cgi-bin/cliMAIN.pl?utlogu). Consequently, the buffalograss and kentucky bluegrass were irrigated 5 and 10 times, respectively, from midJune to late August. Conditions were hotter and drier than average in 2001, when daily maximum air temperatures were 31,34 , and $33^{\circ} \mathrm{C}$ in June, July, and August respectively. Cumulative ET was $557 \mathrm{~mm}$ and total rainfall was $20 \mathrm{~mm}$. This water balance resulted in 16 irrigations in 2001 of the kentucky bluegrass and five irrigations of the buffalograss from early June to late August.

Tree water status in response to irrigation treatments was assessed weekly over the 2000 growing season, and during the period without irrigation in 2001, by measuring predawn leaf water potentials with a Schölander-type pressure chamber(model 3005; Soilmoisture Equipment, Santa Barbara, Calif.) once weekly. One leaf per tree with an intact petiole was removed with a razor blade, sealed in an airtight, plastic bag, and then stored in a cooler until leaf water potential was measured a few minutes later. Immediate measurements of leaf water potential were not possible due to the distance between the trees and the pressure chamber.

Treestomatal conductancealsowas measured within 1 to 2 h of solarnoon onceperweek in 2000 with a steady-state porometer(LI-1600; LI-COR, Lincoln, Nebr.). Five fully exposed leaves and two leaves in the shade were measured to obtain an average of canopy stomatal conductance. Two morning-to-evening studies were done during 2000 (15 June and 29 Aug.). Stomatal conductance of the trees was measured every 2 $h$ on seven leaves per tree. Temperature of each leaf blade was also measured with a handheld infrared thermocouple transducer(model IRT-S; Apogee Instruments, Logan, Utah). Incoming shortwave radiation, airtemperature, and relative humidity were also tracked over both days with the adjacent weather station.

Treatment effects on tree growth were determined by measuring trunk diameter growth with an electronic digital caliper (model P6394; SHAN, China) at the beginning and end of the growing season. Leaf area was determined by defoliating all trees at the end of Septemberofboth years. A subsample of 20 leaves was randomly selected from each tree and measured with a leaf areameter(modelCI-203 with CI-203Aconveyor attachment; CID Inc., Vancouver, Wash.). Total foliage dry weight was obtained after drying all leaves at $60{ }^{\circ} \mathrm{C}$ for $24 \mathrm{~h}$. Ratios of leaf area to dry weight were multiplied by the dry weight of all the leaves to estimate total leaf area for each tree (Montague et al., 2000).

Data were analyzed by using the general linear models procedure and the Tukey-Kramer multiple comparisons option of SAS/STAT software, Version 8 (1999) (SAS Inst., Cary, N.C.).

\section{Results and Discussion}

Trees in the mulched and frequently irrigated treatments did not exhibit water stress during 2000; values of predawn leaf water potential remained from nearly -0.3 to $-0.6 \mathrm{MPa}$ (Fig. 1 ). Lower values of predawn leaf water potentials 
indicated that the trees in precision-irrigated kentucky bluegrass were under mild water stress in early June for nearly $7 \mathrm{~d}$ (Fig. 1). While predawn leafwaterpotentials of trees in precision-irrigated kentucky bluegrass remained lower than those for the mulched and frequently irrigated trees until mid-July, they were not different (Fig. 1). Water stress was more pronounced for trees in precision-irrigated buffalograss, as indicated by predawn leaf water potentials that were lower than those of trees in the other treatments during three dry periods between irrigations in late June, July, and August (Fig. 1). This may have been due to the amount of water applied, which was $76 \%$ of the total amount of water applied to the frequent-replacement-irrigated kentucky bluegrass. Predawn leaf water potentials of trees in precision-irrigated buffalograss recovered after 28 June 2000 and were similar to those of trees in the other treatments when evaporative demand was low (Fig. 1). Water stress was not manifest in any of the turfgrass species in both years, regardless of treatment.

During the treatment period in 2000 , the pattern of change of midday stomatal conductance was similar to that of predawn leaf waterpotential in the precision-irrigated buffalograss relative to that of the trees in the other treatments (Fig. 2). Consistent with values of predawn leaf water potential, trees in precision-irrigated buffalograss had lowervalues of midday stomatal conductance than those of trees in the other treatments through most of the study period, but differences were not significant until mid- to late August (Fig. 2).

Morning-to-evening stomatal conductance values (Fig. 3A and B) were consistent with the weekly midday stomatal conductance measurements in relation to treatment differences within species. On 15 June, trees in all treatments exhibited midday stomatal closure. However, on 29 Aug., there was a reduction in midday stomatal conductance for trees in the precisionirrigated buffalograss and a concurrent increase in leaf temperature later in the day (Fig. 3B and D). Although incoming shortwave radiation, air temperature, and relative humidity had similar patterns on both measurement dates, cloud cover resulted in less incoming shortwave radiation on 29 Aug. 2000 (Fig. 3E and F).

There were no differences in total leaf area of trees across irrigation treatments in 2000 (Table 1). The differences in predawn leaf waterpotential and midday stomatal conductance observed in the trees in the precision-irrigated treatments, particularly for those in precision-irrigated buffalograss, were manifested in decreased trunk diameter growth (Table 1). There were also no differences among values of trunk diameter growth of trees when compared in a two-way analysis of variance for species, irrigation, or species-treatment combination effects (Table 1).

There was an effect of turfgrass species on both total leaf area and trunk diameter growth in 2001 (Table 1). During the period without irrigation frommid-August 2001 untilmid-September 2001 predawn leaf water potential declined from -0.5 to $-0.8 \mathrm{MPa}$, but there were no differences among treatments (datanotshown). Total leafarea of trees grown in precision-irrigated kentucky bluegrass was only $46 \%$ of that of trees grown in frequently irrigated buffalograss (Table 1).
There were, however, no differences in total leaf area among trees grown in precision-irrigated turfgrass of either species or trees in frequently irrigated kentucky bluegrass. Trunk diameter growth of trees grown in frequently irrigated kentucky bluegrass was only $29 \%$ of that of the trees grownin buffalograss of both irrigation treatments after the second year (Table 1), suggesting a competition effect from kentucky bluegrass. There also may have been an allelopathic effect of the kentucky bluegrass roots on the growth of the trees (Bosy and Reader, 1995; Fales and Wakefield, 1981). More work needs to be done to investigate this possibility.

It appears that, regardless of treatment, all trees had become established within $56 \mathrm{~d}$ after transplanting based on the relatively less negative values of predawn leaf water potential at the beginning of the treatment period in 2000 (Fig. 1). Two months after planting, predawn leaf water potential of the trees was -0.3 to -0.6 $\mathrm{MPa}$ (Fig. 1). According to Abod and Webster

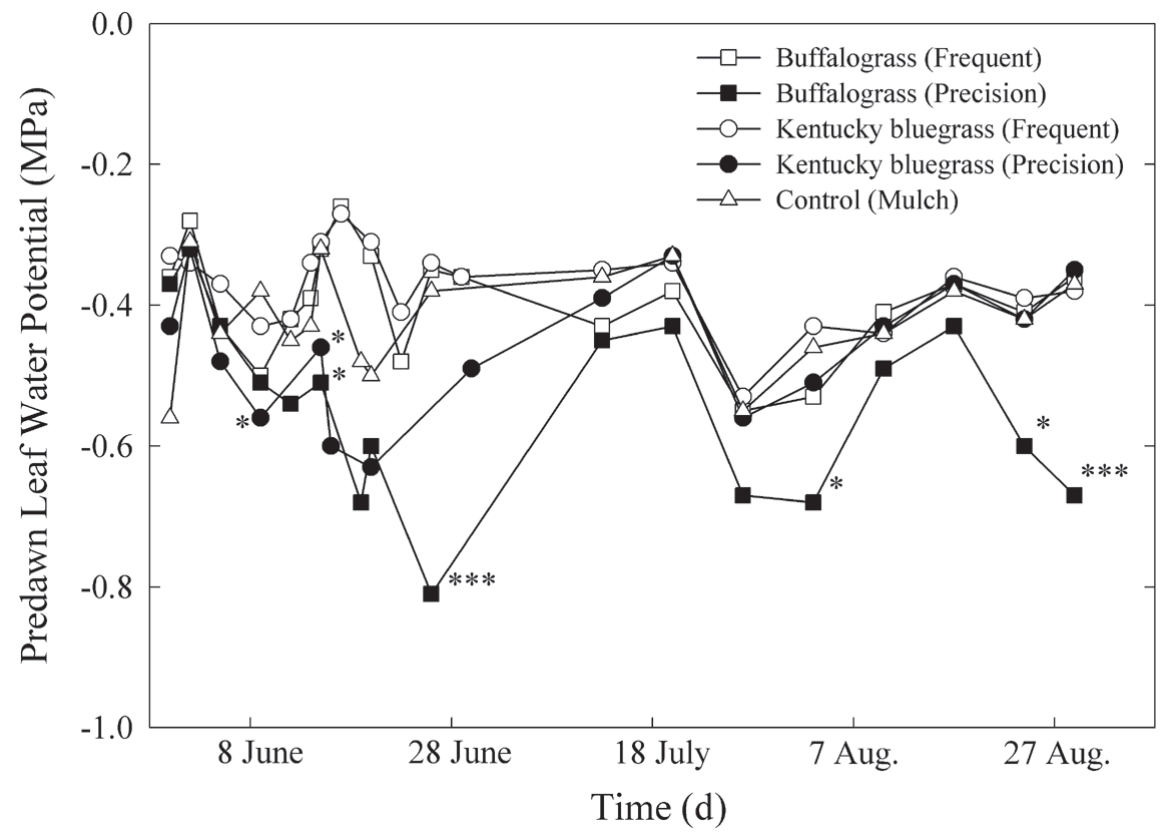

Fig. 1. Predawn leaf water potential of littleleaf lindens (Tilia cordata Mill. 'Greenspire') in five turfgrass species-treatment combinations in $2000\left({ }^{*, * *, * * * *}\right.$ Significant at $P \leq 0.05,0.01$, and 0.001 levels, respectively) of frequently irrigated buffalograss (Buchloë dactyloides [Nutt.] Engelm. 'Tatanka') and kentucky bluegrass (Poa pratensis L.), precision-irrigated kentucky bluegrass and buffalograss, and a mulched control. Values are means of four replications per species-treatment combination.

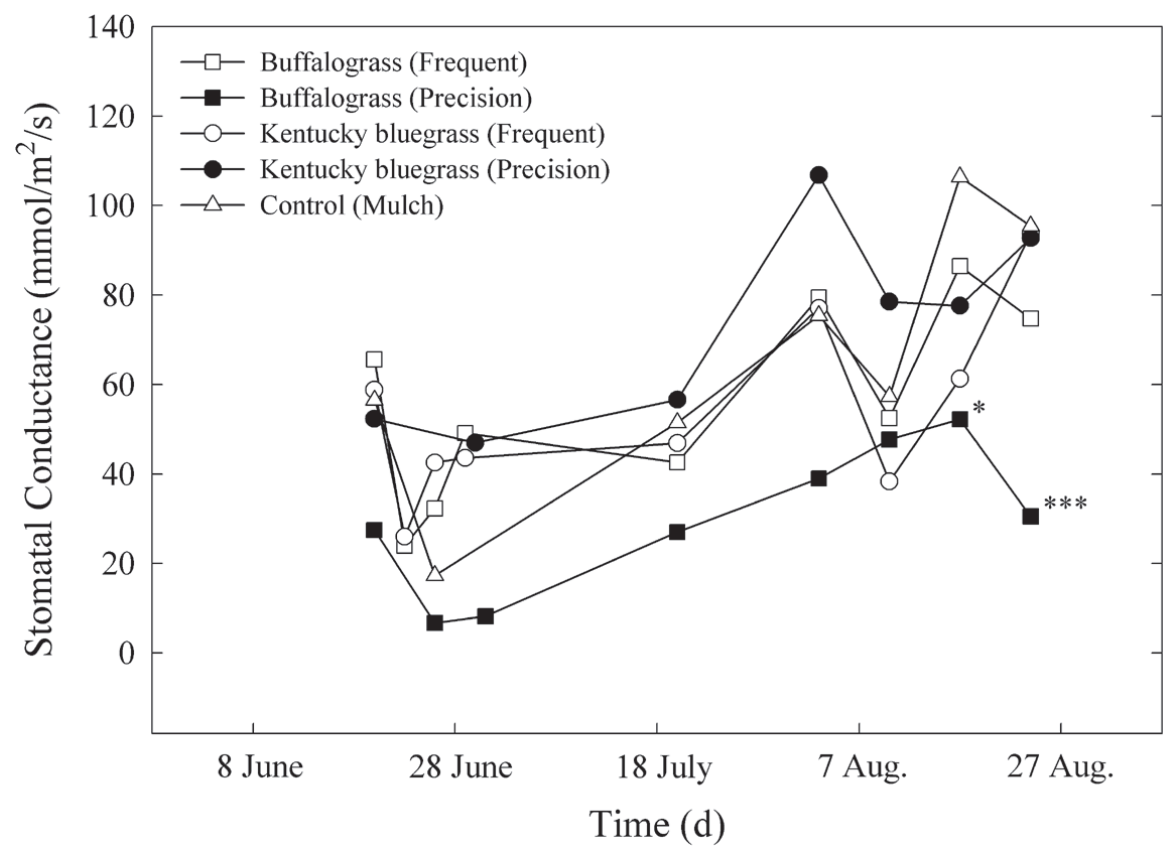

Fig. 2. Midday stomatal conductance readings for littleleaf lindens in 2000 (Tilia cordata Mill. 'Greenspire') in five turfgrass species-treatment combinations $\left({ }^{* * * * *}\right.$ Significant at $P \leq 0.05$ and 0.001 levels, respectively) of frequently irrigated buffalograss (Buchloë dactyloides [Nutt.] Engelm. 'Tatanka') and kentucky bluegrass (Poa pratensis L.), precision-irrigated kentucky bluegrass and buffalograss, and a mulched control. Values are means of four replications per species-treatment combination. 


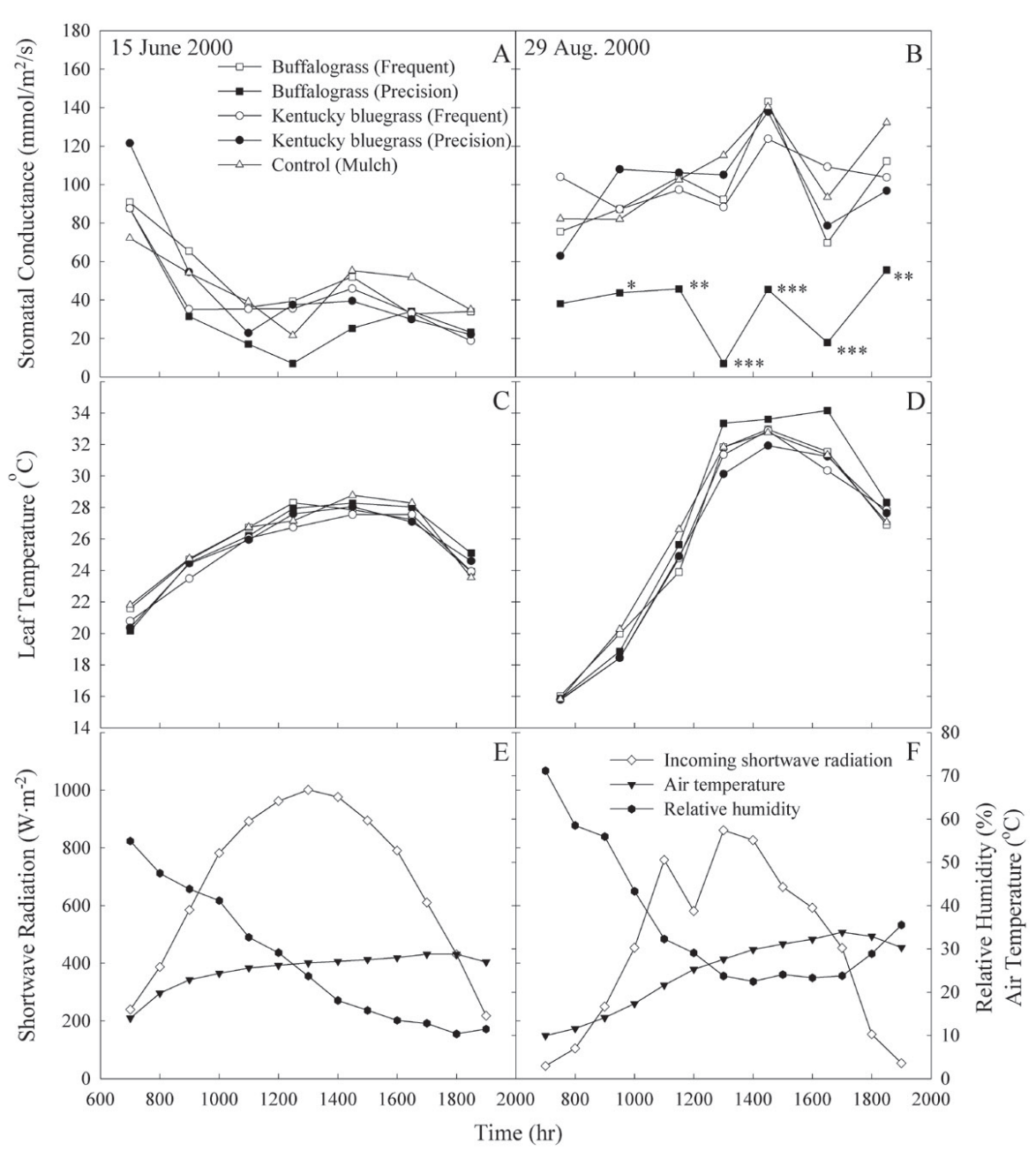

Fig. 3. Morning-to-evening stomatal conductance (A and B) and leaf temperature of littleleaf lindens (Tilia cordata Mill. 'Greenspire') in five turfgrass species-treatment combinations (C and D); and morning-to-evening incoming shortwave radiation, relative humidity, and air temperature $(\mathbf{E}$ and $\mathbf{F})$ on 15 June and 29 Aug. 2000;,${ }^{* * * * * * * *}$ Significant at $P \leq 0.05,0.01$, and 0.001 levels, respectively. Trees were grown in frequently irrigated buffalograss (Buchloë dactyloides [Nutt.] Engelm. 'Tatanka') and kentucky bluegrass (Poa pratensis L.), precision-irrigated buffalograss and kentucky bluegrass, and mulch. Values are means of four replications per turfgrass species-treatment combination.

(1991), new roots of littleleaf linden initiate slowly. However, it appears the trees were able to establish relatively quickly; they were likely able to regenerate new roots soon after transplanting. Establishment occurs when a balance between root absorptive area and transpiring leaf area occurs (Gilman, 1992). Montague et al. (2000) found that before establishment $126 \mathrm{~d}$ after transplanting, 'Greenspire' littleleaf linden trees had values of predawn leaf water potentials near $-1.6 \mathrm{MPa}$, whereas after establishment, average predawn leaf water potential was -0.8 $\mathrm{MPa}$. Unirrigated, transplanted, field-grown silvermaple (Acersaccharinum L.) and kentucky coffeetrees (Gymnocladus dioicus [L.] K. Koch) grown in Illinois required 91 d after transplanting and two growing seasons, respectively, to reach nontransplant predawn leaf waterpotential levels (Kjelgren and Cleveland, 1994). Some contend that alleviation of transplant shock, as indicated by recovery to pre-transplant predawn leaf water potentials, typically takes two or more growing seasons (Beeson, 1994), possibly due to the residual effect of osmotic adjustment (Turner and Jones, 1980). Although the trees in our study in 2000 had only been established for one growing season, they were not under water stress, due to frequent initial irrigations and their relatively small caliper size.

Application of the precision-irrigated treatments in buffalograss and kentuckybluegrass had a negative effect on predawn leaf water potential by early June 2000 (Fig. 1). Later in the season the interval between irrigations, and lack of rain, resulted in pronounced water stress for the trees in precision-irrigated buffalograss as indicated by comparatively larger negative values of predawn leaf water potential and midday stomatal conductance (Figs. 1 and 2). The shorter interval between irrigation of precision-irrigated kentucky bluegrass, however, likely enabled the trees to avoid water stress as indicated by their relatively high predawn leaf water potentials and stomatal conductance (Figs. 1 and 2). The similarities in leaf area and trunk growth between those of trees in precision-irrigated buffalograss and those of the control treatment represent evidence that the trees in precision-irrigated buffalograss were able to recover after irrigations (Table 1). Fernandez et al. (1997) observed similar recovery results after applying water to young apple trees (Malus $\times$ domestica Borkh. 'Imperial Gala') that were previously under water stress.

The minimal effect of irrigation treatments on tree growth during the first year after transplanting was likely due to transplanting effects that obscured the effect of water stress. Root loss of balled-and-burlapped trees can negatively effect leaf area and shoot elongation (Kjelgren and Cleveland, 1994). Tree leaf area is sensitive to water stress over time (Mills et al., 1996). Total tree leaf area would not be as affected during the firstyear after planting because the effect of stress occurred later in the season after cessation of leaf growth (Palmer, 1988). There would, however, be an effect likely shown during the second year.

Table 1. Average total tree leaf area and trunk diameter growth of littleleaf lindens (Tilia cordata Mill. 'Greenspire') growing in precision-irrigated and frequently irrigated buffalograss (Buchloë dactyloides [Nutt.] Engelm. 'Tatanka') and kentucky bluegrass (Poa pratensis L.). Results are shown for one-way and two-way analyses of variance. Values are means of four replications per species-treatment combination and four replications per control treatment.

\begin{tabular}{|c|c|c|c|c|c|}
\hline \multirow[b]{3}{*}{ Species } & \multirow[b]{3}{*}{ Treatment } & \multicolumn{4}{|c|}{ One-way analysis of variance } \\
\hline & & \multicolumn{2}{|c|}{ Total leaf area $\left(\mathrm{m}^{2}\right)$} & \multicolumn{2}{|c|}{ Trunk diameter growth (mm) } \\
\hline & & 2000 & 2001 & 2000 & 2001 \\
\hline Buffalograss & Precision & $0.89 \mathrm{a}$ & $1.51 \mathrm{ab}$ & $0.87 \mathrm{a}$ & $5.77 \mathrm{a}$ \\
\hline Kentucky bluegrass & Frequent & $1.04 \mathrm{a}$ & $1.26 \mathrm{ab}$ & $2.13 \mathrm{a}$ & $1.91 \mathrm{~b}$ \\
\hline Kentucky bluegrass & Precision & $0.92 \mathrm{a}$ & $1.10 \mathrm{~b}$ & $1.04 \mathrm{a}$ & $4.61 \mathrm{ab}$ \\
\hline Mulch (control) & & $1.05 \mathrm{a}$ & $2.18 \mathrm{a}$ & $1.14 \mathrm{a}$ & $7.31 \mathrm{a}$ \\
\hline Species & & 0.32 & 0.04 & 0.81 & $<0.01$ \\
\hline Irrigation & & 0.14 & 0.14 & 0.11 & 0.59 \\
\hline Species $\times$ irrigation & & 0.52 & 0.3 & 0.99 & 0.02 \\
\hline
\end{tabular}

${ }^{2}$ Treatment means within each column followed by the same lower-case letter are not different at $P \leq 0.05$ according to Tukey's honestly significant difference test. 
Trunk growth would more likely be affected by mid- to late-season water stress because it occurs over more of the growing season than do leaf development and expansion.

The effect of precision irrigation, however, must be considered broadly. While not significant at accepted probability levels, the combined irrigation effect in a two-way comparison in 2000 showed that the precision-irrigated trees trended toward less trunk growth $(P \leq 0.11)$ and leaf area $(P \leq 0.14)$. This result suggests that the prudent approach to irrigating turfgrass with newly planted trees would be frequent applications. This approach could still conserve water by basing application amount on ET, but the trees would have adequate soil water between irrigations to avoid water stress. Although more water was applied to precision-irrigated buffalograss in 2001 than that of the other species-treatment combinations, much of the water likely leached through the soil, rendering it unavailable for plant consumption. High-frequency irrigations would probably be unavoidable in a coarse soil due to its lower water-holding capacity. The depletion threshold would also be higher in a coarse soil at higher water contents than in a fine-textured soil with a higher water holding capacity (Kjelgren et al., 2000a),

Particularly notable is the effect of kentucky bluegrass on tree growth observed in 2001. Kentucky bluegrass had a greater competition effect on trunk diameter growth than did buffalograss (Table 1). Kentucky bluegrass has a very high proportion of its roots within $30 \mathrm{~cm}$ of the surface (Stewartetal.,2004; Watson, 1988), whileroots of buffalograss are more evenly distributed through the rootzone(Stewart etal., 2004; Weaver, 1958). Consequently, the level of competition with buffalograss was less near the surface, where most tree roots are located (Hernández-Leos, 1998; Watson and Himelick, 1982). Although not measured directly, we assume that kentucky bluegrass competition near the surface was for all available resources, space as well as water. The absence of signs of water stress during the period without irrigation in 2001 could have been due to the relatively low total tree leaf area. There may have been a relatively low demand on water; thus the smaller trees in the kentucky bluegrass would not deplete soil water as rapidly as those with a higher total leaf area. Over time, however, as tree crown size increases, we presume that shading of turfgrass will shift the competitive advantage for water to trees, particularly those growing in buffalograss, because it is much less shade tolerant than kentucky bluegrass (Quinn, 1998). In addition, further work is needed to analyze the competitive and allelopathic effects of kentucky bluegrass on the distribution of tree roots.

\section{Literature Cited}

Abod, S.A. and A.D. Webster. 1991. Carbohydrates and their effects on growth and establishment of Tilia and Betula: I. Seasonal changes in soluble and insoluble carbohydrates. J. Hort. Sci. 66:235-246.

Allen, R.G., M.E. Jensen, J.L. Wright, and R.D. Burman. 1989. Operational estimates of reference evapotranspiration. Agron. J. 81:650-662.
Ashcroft, G.L., D.T. Jensen, and J.L. Brown. 1992. Utah climate. Utah Climate Center, Utah State Univ., Logan.

Atkinson, D. 1980. The distribution and effectiveness of the roots of tree crops. Hort. Rev. 2:424-490

Beard, J.B. 1973. Turfgrass: Science and culture. Prentice-Hall, Englewood Cliffs, N.J.

Beeson, R.C. 1994. Water relations of fieldgrown Quercus virginiana Mill. from preharvest through containerization and 1 year into the landscape. J. Amer. Soc. Hort. Sci. 119:169-174.

Belsky, A.J. 1994. Influences of trees on savanna productivity: Tests of shade, nutrients, and tree-grass competition. Ecol. 75:922-932.

Bosy, J.L. and R.J. Reader. 1995. Mechanisms underlying the suppression of forb seedling emergence by grass (Poa pratensis) litter. Func. Ecol. 9:635-639.

Caldwell, M.M. 1987. Competition between root systems in natural communities, p. 167-185. In: P.J. Gregory, J.V. Lake, and D.A. Rose (eds.). Root development and function. Cambridge Univ. Press, New York.

Dawson, L.A., E.I. Duff, C.D. Campbell, and D.J. Hirst. 2001. Depth distribution of cherry (Prunus avium L.) tree roots as influenced by grass root competition. Plant and Soil 231:11-19.

Dawson, T.E. 1993. Hydraulic lift and plant water use: Implications for water balance, performance, and plant-plant interactions. Oecologia 95:565-574.

Ervin, E.H. and A J. Koski. 1998. Drought avoidance aspects and crop coefficients of kentucky bluegrass and tall fescue turfs in the semiarid West. Crop Sci. 38:788-795.

Fales, S.L. and R.C. Wakefield. 1981. Effects of turfgrass on the establishment of woody plants. Agron. J. 73:605-610.

Fernandez, R.T., R.L. Perry, and J.L. Flore. 1997. Drought response of young apple trees on three rootstocks. II. Gas exchange, chlorophyll fluorescence, water relations, and leaf abscisic acid. J. Amer. Soc. Hort. Sci. 122:841-848.

Gilman, E.F. 1992. Effect of root pruning prior to transplanting on establishment of southern magnolia in the landscape. J. Arboricult. 18:197-200.

Gist, G.R. and R.M. Smith. 1948. Root development of several common forage grasses to a depth of eighteen inches. Agron. J. 40:1036-1042.

Hernández-Leos, B.A. 1998. Water uptake, water relations, tree growth, and root distribution under herbaceous competition. Utah State Univ., Logan, PhD diss. Abstr. 99-26525.

Horst, G.L., J.C. O'Toole, and K.L. Faver. 1989. Seasonal and species variation in baseline function for determining crop water stress indices in turfgrass. Crop Sci. 29:1227-1232.

Idso, S.B., R.D. Jackson, P.J. Pinter, Jr., R.J. Reginato, and J.L. Hatfield. 1981. Normalizing the stress-degree-day parameter for environmental variability. Agr. For. Meteorol. 24:45-55.

Kjelgren, R. and B. Cleveland. 1994. Growth and water relations of kentucky coffee tree and silver maple following transplanting. J. Environ. Hort. 12:96-99.

Kjelgren, R., N. Chapman, and L. Rupp. 2000a. Tree seedling establishment with protective shelters and irrigation scheduling in three naturalized landscapes in Utah. J. Environ. Hort 18:238-246.

Kjelgren, R., L. Rupp, and D. Kilgren. 2000b. Water conservation in urban landscapes. HortScience 35:1037-1040.

Klingenberg, J.P. 1992. Evaluation, genetic variation, and selection for improvement of a seeded, turf-type buffalograss population. Univ. of Nebraska, Lincoln, PhD diss. Abstr. 93-14407.

Kneebone, W., D. Kopec, and C. Mancino. 1992. Water requirements and irrigation, $p$. 441-472. In: D. Waddington, R. Carrow, and R. Shearman (eds.). Turfgrass. Amer. Soc. Agron., Madison, Wis.

Kozlowski, T.T. 1975. Effects of transplanting and site on water relations of trees. Amer. Nurseryman 141:84-94.

Laiche, Jr., A.J., W.W. Kilby, and J.P. Overcash. 1983. Root and shoot growth of field- and container-grown pecan nursery trees five years after transplanting. HortScience 18:328-329.

Mills, T.M., M.H. Behboudian, and B.E. Clothier. 1996. Water relations, growth, and the composition of 'Braeburn' apple fruit under deficit irrigation. J. Amer. Soc. Hort. Sci. 121:286-291.

Mintenko, A.S., S.R. Smith, and D.J. Cattani. 2002. Turfgrass evaluation of native grasses for the northern Great Plains region. Crop Sci. 42:2018-2024.

Montague, T., R. Kjelgren, and L. Rupp. 2000. Gas exchange and growth of two transplanted, field-grown tree species in an arid climate. HortScience 35:763-768.

Or, D. 1990. Irrigation management considering soil variability and climatic uncertainty. Utah State Univ., Logan, PhD diss. Abstr. 90-34086.

Palmer, J.W. 1988. Annual dry matter production and partitioning over the first 5 years of a bed system of Crispin/M.27 apple trees at four spacings. J. Appl. Ecol. 25:569-578.

Quinn, J.A. 1998. Natural expansion of Buchloe dactyloides at a disturbed site in New Jersey and its implications for turf and conservation uses. J. Torrey Bot. Soc. 125:319-323.

SAS/STAT Software, version 8 of the SAS system for Windows. Copyright 1999. SAS Inst., Cary, N.C.

Stewart, J. R., R. Kjelgren, P.G. Johnson, and M.R. Kuhns. 2004. Soil-water-use characteristics of precision-irrigated buffalograss and kentucky bluegrass. Online. Applied Turfgrass Sci. doi:10.1094/ATS-2004-1118-01-RS.

Turner, N.C. and M.M. Jones. 1980. Turgor maintenance by osmotic adjustment: A review and evaluation, p. 87-103. In: N.C. Turner and P.J. Kramer(eds.). Adaptation of plants to water and high temperature stress. Academic Press, New York.

Watson, G.W. 1988. Organic mulch and grass competition influence tree root development. J. Arboricult. 14:200-203.

Watson, G.W. and E.B. Himelick. 1982. Root distribution of nursery trees and its relationship to transplanting success. J. Arboricult. $8: 225-229$

Weaver, J.E. 1958. Summary and interpretation of underground development in natural grassland communities. Ecol. Monogr. 28:55-78. 